\section{Primula Culture and Production}

\author{
M.G. Karlsson
}

Additional IndeX words. primrose, floriculture, cool season crop, potted plant, bedding plant

$\mathrm{T}$ he name Primula or primrose is derived from the word primary or first, referring to the early growth and flowering in spring (Liberty Hyde Bailey Hortorium, 1976). More than 400 species of primula exist in the family Primulaceae (Griffiths, 1994). Other important horticultural genera in this family, besides primula, include pimpernel (Anagallis), rock jasmine (Androsace), persian violet, alpine violet or sowbread (Cyclamen), shooting star or american cowslip (Dodecatheon) and loosestrife (Lysimachia). The genus Primula consists of relatively shortlived perennial herbs with leaves arranged in basal rosettes. The flowers are usually five lobed and solitary in axils or arranged in stalked racemes, umbels or whorls (Griffiths, 1994; Liberty Hyde Bailey Hortorium, 1976). Primula originates from the northern hemisphere, China, Europe and the Mediterranean (Griffiths, 1994; Liberty Hyde Bailey Hortorium, 1976; Ward, 1997).

Several primula species are produced and used as bedding plants or flowering potted plants (Table 1 ). The most important species in production include english primrose or acaulis primula (Primula vulgarissynonym $P$. acaulis) (Blom et al., 1987; Coombes, 1985; Griffiths, 1994), polyanthus, polyantha primrose or hybrid primrose $(P . \times$ polyantha $)$, fairy primrose or baby primrose ( $P$. malacoides), german primrose or poison primrose $(P$. obconica) and cowslip (P. veris). Chinese primrose ( $P$. sinensis) is also produced in limited numbers and some interest exists in producing drumstick

Department of Plant, Animal and Soil Sciences, University of Alaska, Fairbanks, AK 99775-7200.

Use of cultivar, trade or company names does not imply endorsement or approval nor does it imply criticism or disapproval of those cultivar, trade or company names not mentioned. primrose ( $P$. denticulata) as a container plant.

Primula is widely produced in Europe as a flowering potted plant for the late winter and early spring market. In the United States, the growing conditions in the Pacific Northwest are particularly well suited for producing primula. In addition to flowering potted plants, primula is used together with other plants in potted arrangements, color bowls and hanging baskets or as a potted plant for outdoor planting in areas with moderate summer temperatures (Goldsberry, 1980). In recent years, sales in the United States have been primarily of bedding plants in areas with mild winters or early spring elsewhere. For garden and bedding uses, english primrose and polyanthus are considered hardy to zone five (Dole and Wilkins, 1999) while fairy primrose, german primrose and chinese primrose cannot withstand frost (Table 1) (Brickell and Zuk, 1996; Karlsson, 1997). Many commercial interests and gardeners are involved in breeding, propagating and growing the numerous primula species and hybrids. Species that are more appropri- ate for garden plantings include garden auricula ( $P$. xpubescens, a cross between $P$. auricula and $P$. hirsuta), cowslip, julian primrose (P. juliae), siebold primrose ( $P$. sieboldii), and redleaf primrose ( $P$. rosea) (Dole and Wilkins, 1999).

\section{Cultivar development}

Several breeding programs in Europe, Japan and the United States have contributed numerous primula hybrid cultivars and series. The introduction of $F_{1}$ hybrids has resulted in improved germination rates, increased flower size, more uniform flowering and better postharvest quality than open-pollinated selections. Cultivars with unique flower colors, bicolors or features such as distinct centers or delicately outlined petals are continuously added to these $F_{1}$ series. Seeds of most cultivar series are available both segregated into the individual flower colors and as mixtures. Although there is some emphasis on increasing the rate of development, cultivars for intermediate or late marketing have also

Fig. 1. English primrose 'Dania'. 
Table 1. Characteristics of Primula species (Brickell and Zuk, 1996; Dole and Wilkins, 1999; Griffiths, 1994; Karlsson, 1997; Liberty Hyde Bailey Hortorium, 1976; Richards, 1993).

\begin{tabular}{|c|c|c|c|c|c|c|}
\hline $\begin{array}{l}\text { Common } \\
\text { name } \\
\text { some } \\
\text { (scientific name) } \\
\end{array}$ & Origin & $\begin{array}{l}\text { Commonly } \\
\text { grown } \\
\text { cultivar series }\end{array}$ & $\begin{array}{l}\text { Cold } \\
\text { hardiness } \\
\text { zone }\end{array}$ & $\begin{array}{l}\text { Ht } \\
\text { (inches) }^{\mathrm{z}}\end{array}$ & $\begin{array}{l}\begin{array}{l}\text { Leaf } \\
\text { length }\end{array} \\
\text { (inches) }\end{array}$ & $\begin{array}{l}\text { Ch rom o - } \\
\text { no. }(2 \mathrm{n}) \\
\end{array}$ \\
\hline \multicolumn{7}{|l|}{ Chinese primrose } \\
\hline (P. sinensis) & China & Fanfare & $8-10$ & $6-8$ & $3-4$ & $24,36,48$ \\
\hline \multicolumn{7}{|l|}{ Cowslip } \\
\hline (P. veris) & Europe & & $3-8$ & $6-8$ & 10 & 22 \\
\hline $\begin{array}{l}\text { Drumstick primrose } \\
\qquad(P . \text { denticulata })\end{array}$ & $\begin{array}{l}\text { Afghanistan, southeast } \\
\text { Tibet, Burma, China }\end{array}$ & & $2-4$ & 18 & 10 & 22 \\
\hline $\begin{array}{l}\text { English primrose } \\
\qquad(P . \text { vulgaris syn. } \\
\quad P . \text { acaulis })\end{array}$ & Europe, western Turkey & $\begin{array}{l}\text { Danova } \mathrm{F}_{1} \text {, Lovely } \mathrm{F}_{1} \text {, Pageant } \\
\mathrm{F}_{1} \text {, Quantum } \mathrm{F}_{1} \text {, Dania } \mathrm{F}_{1} \text {, } \\
\text { Finesse } \mathrm{F}_{1} \text {, Gemini } \mathrm{F}_{1} \text {, } \\
\text { Daniella } \mathrm{F}_{1} \text {, Joker } \mathrm{F}_{1} \text {, } \\
\text { Paloma } \mathrm{F}_{1}\end{array}$ & $4-5$ & 8 & $2-10$ & 22 \\
\hline $\begin{array}{l}\text { Fairy primrose } \\
\qquad(\text { P. malacoides })\end{array}$ & Burma, China & Prima $F_{1}$ & $8-10$ & $12-18$ & $1-2$ & $18,36,72$ \\
\hline $\begin{array}{l}\text { German primrose } \\
\text { (P. obconica })\end{array}$ & China & $\begin{array}{l}\text { Juno } \mathrm{F}_{1} \text {, Libre } \mathrm{F}_{1} \text {, Twilly } \\
\text { Touch Me } \mathrm{F}_{1}\end{array}$ & 10 & $9-16$ & 6 & 24,48 \\
\hline $\begin{array}{l}\text { Polyanthus } \\
\qquad(\text { P. ×polyantha })\end{array}$ & Hybrid & $\begin{array}{l}\text { Pacific Giant, Concorde } \mathrm{F}_{1} \text {, } \\
\text { Hercules } \mathrm{F}_{1} \text {, Rumba } \mathrm{F}_{1}\end{array}$ & $5-6$ & $10-12$ & 7 & \\
\hline
\end{tabular}

been released in efforts to expand the length of the salesperiod. Another breeding goal has been to synchronize the development and flowering of all cultivars in a series. The onset of flowering frequently varies 2 to 4 weeks with a tendency for faster development of some colors in a cultivar series. A mixture of colors throughout the flowering and marketing phase is desirable in the finished product.

English Primrose. The english primrose has 2- to 10 -inch (5- to 25$\mathrm{cm}$ ) long leaves in a compact rosette as suggested by the word acaulis, meaning stemless (Fig. 1). The flowers develop on individual 2 - to 8 -inch $(5$ - to $20-\mathrm{cm})$ long pedicels from the center of the plant. The native english primrose has pale yellow flowers. Through breeding efforts and the development of $F_{1}$ hybrids, cultivars of english primrose are now available with flowers in many colors from white to red, blue and purple. The flowers may have a yellow or white eye and are sometimes fragrant.

English primrose has been extensively bred and a large number of cultivars are available (Table 1 ). The Danova series was introduced in 1989 by
Daehnfeldt, Inc. (Odense, Denmark) and may be the most widely produced primula cultivar today (Hansen, 2001). The Danova series is intended for early season marketing in November and December in the northern hemisphere from a June seeding. The Danova series comes in more than 20 colors and includes several cultivars with two-toned flowers. Other early season cultivars include the Lovely and the Pageant series bred by the Sakata Seed Corporation (Yokohama, Japan) and the Quantum series from Goldsmith Seeds, Inc. (Gilroy, Calif.). The Lovely series has smaller flowers than the Pageant series although they both have a compact growth habit suitable for 4-inch (10$\mathrm{cm}$ ) or smaller pots. Several red and pink bicolors are included in the Pageant series. The Quantum series is also compact with high and uniform germination rates and good postharvest quality.

The Dania (Daehnfeldt, Inc.), Finesse (Ernst Benary Seed Growers Ltd., Hann. Muenden, Germany) and Gemini (Goldsmith Seeds, Inc.) series are suitable for midseason marketing (January and February). Compared to the Danova series, the Dania series has somewhat larger flowers but a more limited color range. A unique feature of the Finesse series is the narrow silver or gold border of the flower petals. The limited leaf growth of the Gemini series makes it suitable for 4 -inch pots or in combination with other plants in patio planters or color bowls.

Cultivars for late season marketing (February and March) include the Daniella(Daehnfeldt, Inc.), Joker(Ernst Benary Seed Growers Ltd.) and Paloma (Royal Sluis Ornamentals, Leyland, UK) series. The Daniella series was introduced in 1995 as a complement to the Danova series to extend the marketing period. The Joker series consists of both bicolored and clear flowers and the Paloma series is a leading cultivar in Europe.

Polyantrus. The polyanthus is a hybrid, primarily between cowslip, oxlip (P. elatior), english primrose and julian primrose (Griffiths, 1994; Professional Plant Growers Association, 1994). The flowers of polyanthus develop in a cluster on an extended main flower stalk or peduncle (4 to 6 inches, 10 to 15 $\mathrm{cm})$. Sometimes this inflorescence is referred to as the polyanthus type in 


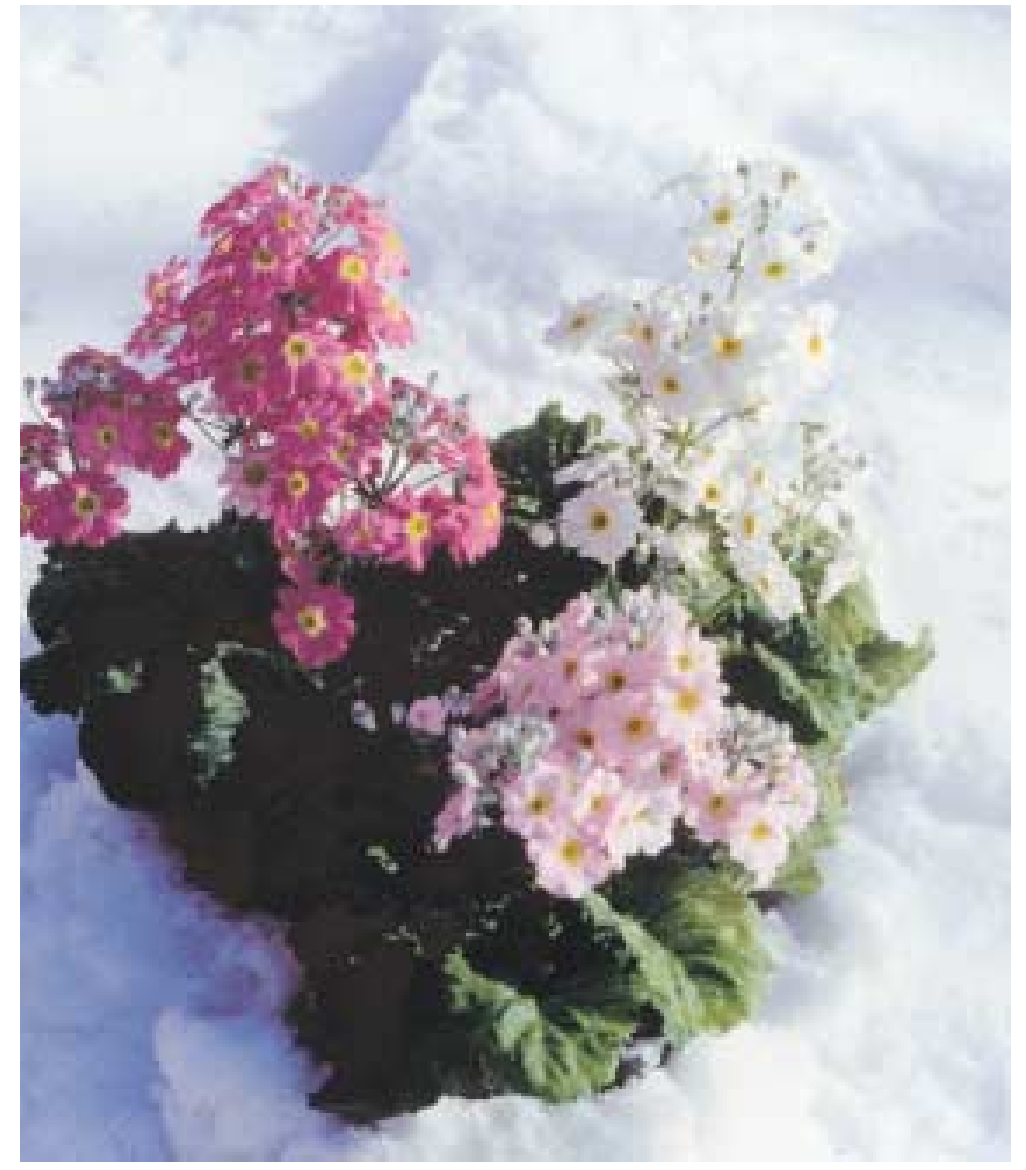

Fig. 2. Fairy primrose Prima’.

contrast to the single pedicel acaulis type (Blom et al., 1987; Erickson, 1986; Kvamme, 1990; Linwick, 1996). Production guidelines, flowering requirements and plant development are similar for polyanthus and english primrose.

The flower colors of polyanthus are dominated by yellows and reds but cultivars with white, pink, maroon, purple, bronze or gold flowers with or without a yellow or white eye are available (Griffiths, 1994). For years, the most important polyanthus cultivar has been the Pacific Giant series (Table 1). The Sakata Seed Corporation has been maintaining and developing the Pacific Giant series since 1968 (Ward, 1997). This vigorous growing cultivar series with long peduncles has large clusters of flowers. The newer Concorde (Daehnfeldt, Inc.), Hercules (Royal Sluis Ornamentals) and Rumba (Goldsmiths Seeds, Inc.) series have more compact but stronger peduncles than the older Pacific Giant series. The Hercules series is also known for its postharvest ability to ship well.

FaIry primrose. The flowers of the fairy primrose (Fig. 2) are arranged to $7.5-\mathrm{cm}$ ) long petioles. The primary use of the fairy primrose is as a flowering potted plant since sensitivity to frost limits bedding and landscape applications (Table 1 ).

The Prima series (Daehnfeldt, Inc.) is the most commonly grown fairy primrose. This series comes as a seed mix of pastel flower colors with a large proportion bicolored pink and rose flowers or segregated into specific flower colors. The expected production time (Table 2 ) is short ( 5 to 6 months) and the growth habit uniform and compact.

German primrose. The german primrose (Fig. 3) has leaves up to 6 inches $(15 \mathrm{~cm})$ long with petioles of 2 to 4 inches $(5$ to $10 \mathrm{~cm})$. Flowers appear in loose upright umbels or clusters on 6- to 7-inch (15- to 17.5-cm) long peduncles. Cultivars are available with flowers in many pleasing soft pastel shades from white to lilac, purple, pink and orange. Expected production time for german primrose varies from 4 to 6 months. The leaves of some german primrose cultivars produce the allergen primin that may cause skin dermatitis (Armitage, 1986; Nau, 1999; Perry, 1981). The risk for allergic reactions has limited the use and production. It is advisable to observe caution when producing, handling and marketing the german primrose and limit exposure by wearing gloves and long sleeves.

The german primrose series Juno

Fig 3. German primrose'Juno'.

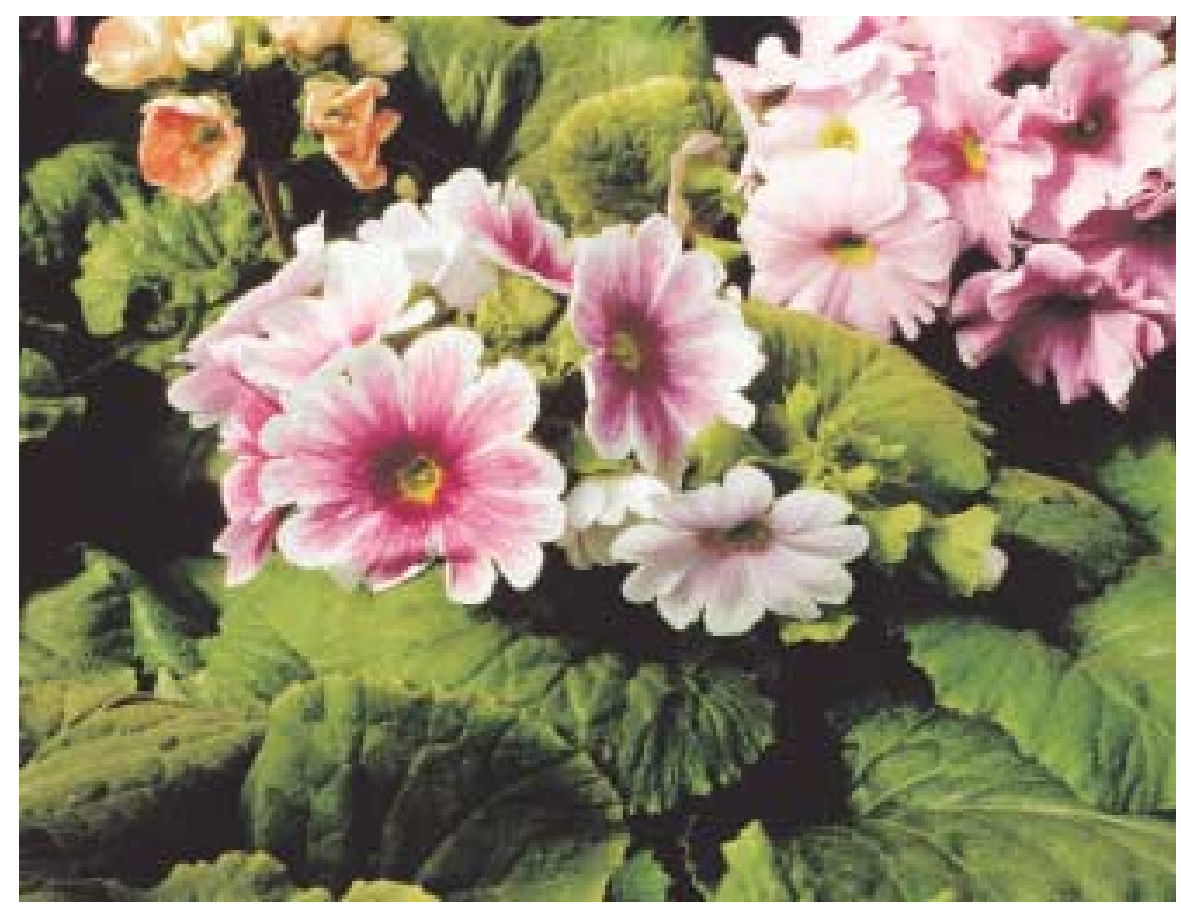


(S\&G Seeds, Downers Grove, Ill.) has been grown extensively in the United States (Table 1). The Juno series has a height of 12 inches $(30 \mathrm{~cm})$, relatively small leaves and abundant flowering. The recent development and introduction of cultivars that do not produce primin has reduced the skin rash problem and renewed the interest in german primrose. The first cultivars stated to lack primin were introduced in 1990 under the names 'Freedom' and 'Beauty' (Richards, 1993). Some individuals however, developed a skin rash following direct contact with these cultivars claimed to contain no allergen. In 1995, the Libre series (Goldsmith Seeds, Inc.) was released as the first true primin-free selection of the german primrose. The Libre series grows shorter than the Juno series at 8 to 10 inches $(20$ to $25 \mathrm{~cm}$ ), is suitable for 4 to 6 -inch ( 10 to $15-\mathrm{cm}$ ) pots and comes in several flower colors including white, pink, salmon, red and blue. Schoneveld (Twello, The Netherlands) recently released the primin-free Twilly Touch Me series (James and Beytes, 2001).

Chinese primrose. The leaves of the chinese primrose have a rounder shape than the other species discussed here and the leaf margins are dentate or scalloped. Cold hardiness is limited to zones 8 to 10 (Table 1 ). The flowers of the chinese primrose form clusters on 4 to 6-inch (10-to 15-cm) long peduncles. Various flower colors are available from white, purple to pink (Griffiths, 1994). Pigments often color the roots and the lower sides of the leaves red. The Fanfare series (Daehnfeldt, Inc.) is produced in 5 to 6 months and has exceptionally good shelf life. The flowers are large and the foliage has a dark green color.

Drumstick primrose. Selections of drumstick primrose are suggested to survive temperatures down to $-50^{\circ} \mathrm{F}(-$ $46^{\circ} \mathrm{C}$ ) (Table $\mathrm{l}$ ) and have potential for marketing as a flowering potted perennial for northern landscapes (Nau, 1999). Flowers appear in a dense globular cluster on a peduncle. The flower color is white or various shades of purple.

CowsLIP. The cowslip has fragrant, bright yellow flowers on an extended peduncle and is used in rock, alpine or other types of gardens (Liberty Hyde Bailey Hortorium, 1976). Selections with flower colors in other than yellow (orange, apricot, crimson, light purple and white) are now offered (Dole and
Wilkins, 1999). The ability to withstand low temperatures varies for cowslip from zone $3\left(-40\right.$ to $-30^{\circ} \mathrm{F}\left[-40\right.$ to $\left.\left.-34^{\circ} \mathrm{C}\right]\right)$ to zone $8\left(10\right.$ to $20^{\circ} \mathrm{F}\left[-12\right.$ to $\left.\left.-7^{\circ} \mathrm{C}\right]\right)$ (Table 1).

\section{Propagation}

Primula is exclusively propagated by seed (Dole and Wilkins, 1999; Karlsson, 1997; Nau, 1999; Perry, 1981; Wandås, 1991). English primrose, polyanthus and chinese primrose have seeds of similar size at 28,000 seeds/oz (990 seeds/g) (Hartnett, 1993; Nau, 1999). German primrose has 175,000 seeds/oz (6,170 seeds/ $\mathrm{g})$ and the fairy primrose has the smallest seed with 360,000 seeds $/ \mathrm{oz}$ $(12,700$ seeds/g) (Hartnett, 1993). Germination is often erratic and low for primula (Dole and Wilkins, 1999; Hartnett, 1993, McNertney et al., 1991). Improved seed quality and close attention to moisture and temperature conditions have improved germination uniformity and rates. A welldrained peatlite medium works well for germination and early seedling development. Hartnett (1993) recommends a medium of $60 \%$ fine peat, $25 \%$ perlite and $15 \%$ vermiculite for primula

Table 2. Summary of recommended environmental conditions for the production of english primrose (Primulamigaris), polyanthus (P. xpolyantba), fairy primrose (P.malacoides) and german primrose (P.obconica).

\begin{tabular}{|c|c|c|c|c|}
\hline \multirow[b]{2}{*}{ Species } & \multirow{2}{*}{$\begin{array}{l}\text { Temp } \\
\left({ }^{\circ} \mathbf{F}\right)^{\mathbf{z}}\end{array}$} & \multicolumn{2}{|c|}{ Irradiance } & \multirow[b]{2}{*}{ Comments } \\
\hline & & Photoperiod & Intensity & \\
\hline \multicolumn{5}{|l|}{ Germination } \\
\hline Fairy primrose & $60-65$ & \multirow{2}{*}{\multicolumn{2}{|c|}{$\begin{array}{l}\text { species although beneficial } \\
\text { immediately upon germination }\end{array}$}} & 2 weeks \\
\hline German primrose & $65-68$ & & & $10 \mathrm{~d}-2$ weeks \\
\hline \multicolumn{5}{|l|}{ Early plant development } \\
\hline German primrose & $60-68$ & long day & $\approx 10 \mathrm{~mol} \cdot \mathrm{d}^{-1} \cdot \mathrm{m}^{-2}$ & $6-8$ weeks \\
\hline \multicolumn{5}{|l|}{ Flower initiation } \\
\hline English primrose and polyanthus & $55-60$ & long day & $\begin{array}{l}>10 \mathrm{~mol} \cdot \mathrm{d}^{-1} \cdot \mathrm{m}^{-2} \\
\text { peak: }<600 \mu \mathrm{mol} \cdot \mathrm{m}^{-2} \cdot \mathrm{s}^{-1}\end{array}$ & $\begin{array}{l}\text { Recent cultivars do not require a cold } \\
\text { treatment }\end{array}$ \\
\hline Fairy primrose & $45-50$ & day neutral & $\approx 10 \mathrm{~mol} \cdot \mathrm{d}^{-1} \cdot \mathrm{m}^{-2}$ & 6 weeks \\
\hline Fairy primrose & $57-65$ & long day & $\approx 10 \mathrm{~mol} \cdot \mathrm{d}^{-1} \cdot \mathrm{m}^{-2}$ & Photoperiod applies to 'Prima' \\
\hline German primrose & $65-68$ & long day & $\approx 10 \mathrm{~mol} \cdot \mathrm{d}^{-1} \cdot \mathrm{m}^{-2}$ & $\begin{array}{l}\text { Photoperiod applies to 'Libre', day } \\
\text { neutral at } 60^{\circ} \mathrm{F}\end{array}$ \\
\hline \multicolumn{5}{|l|}{ Finish before marketing } \\
\hline English primrose and polyanthus & $55-60$ & any & $\geq 5 \mathrm{~mol} \cdot \mathrm{d}^{-1} \cdot \mathrm{m}^{-2}$ & $\begin{array}{l}\text { Expected production time of } 5.5-6.5 \\
\text { months }\end{array}$ \\
\hline Fairy primrose & $57-60$ & any & $\geq 5 \mathrm{~mol} \cdot \mathrm{d}^{-1} \cdot \mathrm{m}^{-2}$ & Expected production time of $5-6$ months \\
\hline German primrose & $60-65$ & any & $\geq 5 \mathrm{~mol} \cdot \mathrm{d}^{-1} \cdot \mathrm{m}^{-2}$ & Expected production time of $4-6$ months \\
\hline
\end{tabular}


plug production. The sowing medium should have a low nutrient content and a $\mathrm{pH}$ between 5.5 and 6.0 (Linwick, 1996). A medium electrical conductivity (EC) less than $0.75 \mathrm{dS} \cdot \mathrm{m}^{-}$ ${ }^{1}$ is essential as high soluble salt levels may interfere with germination (McNertney et al., 1991).

Recommended germination temperature is $60^{\circ} \mathrm{F}\left(16^{\circ} \mathrm{C}\right)$ for english primrose, polyanthus and chinese primrose, 60 to $65^{\circ} \mathrm{F}\left(16\right.$ to $18^{\circ} \mathrm{C}$ ) for the fairy primrose and 65 to $68^{\circ} \mathrm{F}$ (18 to $20^{\circ} \mathrm{C}$ ) for german primrose (Table 2 , Hartnett, 1993; Nau, 1999). Hammer (1992) and Miller and Holcomb (1982) stress the importance of maintaining the temperature below $70^{\circ} \mathrm{F}$ $\left(21^{\circ} \mathrm{C}\right)$ for english primrose and polyanthus while Chavagnat and Jeudy (1981) reported 59 to $77^{\circ} \mathrm{F}$ ( 15 to 25 $\left.{ }^{\circ} \mathrm{C}\right)$ suitable for germination of german primrose. Kvamme (1990) exposed english primrose seed to 41 to $50^{\circ} \mathrm{F}(5$ to $10^{\circ} \mathrm{C}$ ) for 1 or 2 weeks to improve germination at $65^{\circ} \mathrm{F}$ but Hartnett (1993), however, stated chilling had little effect on germination. The variation in response to chilling may be due to differences in cultivar and seed quality. One breeding goal has been to improve germination. The currently available cultivars have faster and more uniform germination rates and do not appear to require or benefit from a low temperature seed treatment.

Studies examining the impact of the germination temperature on the continued development to flower are limited. Kvamme (1990) germinated the english primrose 'Dania' at 54 or $64^{\circ} \mathrm{F}\left(12\right.$ or $\left.18^{\circ} \mathrm{C}\right)$ with the former temperature slowing germination by 4 d. For plants germinated at $54^{\circ} \mathrm{F}$ and then moved to $64^{\circ} \mathrm{F}$, flowering was delayed up to $30 \mathrm{~d}$ depending on light conditions. Lower germination temperatures also can result in smaller plants with fewer leaves and shoots at flowering.

Gibberellic acid treatments have been suggested to improve germination (Dole and Wilkins, 1999; McNertney et al., 1991; Miller and Holcomb, 1982). Higher germination rates were obtained for polyanthus after the seeds were submerged in $250 \mathrm{ppm}\left(\mathrm{mg} \cdot \mathrm{L}^{-1}\right)$ gibberellic acid for $12 \mathrm{~h}$ (Miller and Holcomb, 1982). However gibberellic acid did not affect germination of english primrose.

Several reports (Dole and Wilkins, 1999; Karlsson, 1997; McNertney et al., 1991; Nau, 1999; Styer and Koranski, 1997) indicate most primula cultivars require light for maximum germination. Linwick (1996) and Professional Plant Growers Association (1994), however, found light is not necessary for germination but is useful for controlling the height of seedlings immediately after germination (Table $2)$. In addition to providing light, sufficient moisture appears crucial for good germination and early seedling development (Aimone, 1987; Cathey, 1969; Karlsson, 1997; Wikesjö, 1975). Covering the seeds with a layer of vermiculite, perlite or any well aerated medium can be used to improve the humidity around the seeds. The layer must remain thin due to the potential light requirement. The small seeds of the fairy primrose and the german primrose especially benefit from a thin cover to avoid desiccation. For english primrose and polyanthus, a protective layer can be added later when the radicle emerges 7 to $10 \mathrm{~d}$ after seeding (Hartnett, 1993; Karlsson, 1997; Linwick, 1992).

\section{Early plant development}

The germination process requires $10 \mathrm{~d}$ to 2 weeks. Following germination, the temperature can continue at 60 to $65^{\circ} \mathrm{F}$ for english primrose, polyanthus and the fairy primrose, and 65 to $68{ }^{\circ} \mathrm{F}$ for the german primrose (Table 2) (Mureaoka, 2000). After 6 to 8 weeks, the seedlings should have two or three true leaves and are suitable for transplanting (Blom et al., 1987; Kromer, 1991; Linwick, 1996; Wikesjö, 1975).

A single seedling is planted in a 3or 4-inch pot. For larger pots, two or more seedlings are used (Hartnett, 1993). Similar to the germination medium, the growing medium should be high in organic matter and well drained at a $\mathrm{pH}$ of 5.5 to 6.0 (Linwick, 1996). The planting depth should be the same as in the seedling flat to avoid crown rot and other diseases. The plants are spaced when the leaves reach the edge of the pot. Suitable final spacing for 4 -inch pots is 4 pots $/ \mathrm{ft}^{2}$ ( 42 to 44 pots $/ \mathrm{m}^{2}$ ) (Hartnett, 1993; Wandås, 1991).

\section{Flowering requirements}

ENGLISH PRIMROSE AND POLYANTHUS-HISTORICAL RECOMMENDATIONS. Production guidelines for flower initiation in english primrose and poly- anthus include several weeks at 40 to $50{ }^{\circ} \mathrm{F}\left(4\right.$ to $\left.10{ }^{\circ} \mathrm{C}\right)$ (Hartnett, 1993; Linwick, 1992; 1996; Perry, 1981; Salamati, 1988; Wandås, 1991). The temperature is dropped when plants have developed a good root system and six to ten leaves. To promote bud set, some growers increase the fertilizer rate from 60 to $200 \mathrm{ppm}$ nitrogen and double the potassium rate in relation to nitrogen 2 weeks before temperature drop (Hartnett, 1993). The use of calcium nitrate and potassium nitrate with a low proportion ammonium nitrogen has worked well. When flower buds are visible, the temperature can be increased to between 50 and $55^{\circ} \mathrm{F}\left(10\right.$ to $\left.13{ }^{\circ} \mathrm{C}\right)$ or remain below $50{ }^{\circ} \mathrm{F}$ (Hartnett, 1993; Löfenberg, 1988).

Temperature. Cooling the plants for up to 10 weeks increases the plant quality of english primrose and polyanthus by increasing flower number, maintaining smaller leaf size and reducing the pedicel length (Löfenberg, 1988). The lower temperature however, slows overall rate of plant development. Flower initiation has been observed in plants grown continuously at 59 to $68^{\circ} \mathrm{F}$ (Armitage and Billingsley, 1983; Karlsson, 1997; Kvamme, 1990; Löfenberg, 1988), and the newer cultivars of english primrose and polyanthus do not require a cold treatment (Professional Plant Growers Association, 1994).

Welander and Selander (1981) found that the english primrose 'Aalsmeer Giant' initiated flowers faster at 54 or $59^{\circ} \mathrm{F}$ than at $48^{\circ} \mathrm{F}\left(9^{\circ} \mathrm{C}\right)$. Salamati (1988) observed that flower initiation in the english primrose 'Dania' was slowed up to $45 \mathrm{~d}$ depending on light conditions, at $4 \mathrm{I}^{\circ} \mathrm{F}$ when compared to $59^{\circ} \mathrm{F}$. The slower flower initiation at lower temperatures has been confirmed in more recent studies with rapidly flowering cultivars of the english primrose (Karlsson, 1997). Flower initiation at $46^{\circ} \mathrm{F}\left(8^{\circ} \mathrm{C}\right)$ was especially slow when combined with low light $\left(2 \mathrm{~mol} \cdot \mathrm{d}^{-1} \cdot \mathrm{m}^{-2}\right)$ and short days $(8 \mathrm{~h})$. Estimated optimum temperature for flower initiation was $55^{\circ} \mathrm{F}$ (Karlsson, 1997). Kvamme (1990) also found faster bud initiation at $59{ }^{\circ} \mathrm{F}$ when compared to 64 or $70^{\circ} \mathrm{F}$ in the english primrose 'Dania'. At $75^{\circ} \mathrm{F}(24$ $\left.{ }^{\circ} \mathrm{C}\right)$, the plants failed to initiate flower buds. Increasing temperature from 54 to $64^{\circ} \mathrm{F}$ delayed the continued development to flower both in 'Aalsmeer 
Giant' and 'Ducat' of the english primrose (Selander and Welander, 1984).

A higher night than day temperature (negative DIF) has been suggested to hasten flower initiation in english primrose (Hartnett, 1993; Kvamme, 1990). In studies by Kvamme (1990), flower formation and development was faster with a negative (54/ $70{ }^{\circ} \mathrm{F}$, day/night) than positive DIF $\left(75 / 54^{\circ} \mathrm{F}\right)$ at the same average daily temperature. Especially under short day $(8 \mathrm{~h})$ conditions, negative DIF appears to promote faster bud formation and flowering than constant or positive DIF (Hartnett, 1993).

IRRADIANCE. Even though primula is considered a low light crop (Wandås, 1991), daily irradiance affected flower initiation efficiency. From seeding to floral initiation at $54^{\circ} \mathrm{F}$ and long photoperiods $(>12 \mathrm{~h})$, days to initiation decreased from 72 to $57 \mathrm{~d}$ for english primrose at $10 \mathrm{~mol} \cdot \mathrm{d}^{-1} \cdot \mathrm{m}^{-2}$ compared to $2 \mathrm{~mol} \cdot \mathrm{d}^{-1} \cdot \mathrm{m}^{-2}$. The optimum daily irradiance for flower initiation was estimated to $11 \mathrm{~mol} \cdot \mathrm{d}^{-1} \cdot \mathrm{m}^{-2}$ or about $250 \mu \mathrm{mol} \cdot \mathrm{m}^{-2} \cdot \mathrm{s}^{-1}$ for $12 \mathrm{~h}$ (Karlsson, 1997). High natural light conditions may warrant shading to prevent sunscald and improve temperature control since plant quality of english primrose decreases above $68^{\circ} \mathrm{F}$ (Aimone, 1987; Hartnett, 1993; Kvamme, 1990; Wandås, 1991). Maximum peak irradiance in primula production should not exceed $600 \mu \mathrm{mol} \cdot \mathrm{m}^{-2} \cdot \mathrm{s}^{-1}$ (Hartnett, 1993). For most rapid flower initiation, the optimum daily light integral appears to increase from 11 to 13 $\mathrm{mol} \cdot \mathrm{d}^{-1} \cdot \mathrm{m}^{-2}$ with either an increasing or decreasing temperature from $55^{\circ} \mathrm{F}$ (Hartnett, 1993; Karlsson, 1997; Kvamme, 1990).

Photoperiod. Perry (1981) and Welander and Selander (1981) found short days $(9 \mathrm{~h})$ to result in rapid flower initiation and development of english primrose. In contrast, a longer day was more beneficial for flower initiation in studies by Karlsson (1996, 1997) and Kvamme (1990). Karlsson $(1996,1997)$ found flower induction and initiation were more rapid with long days of $14 \mathrm{~h}$ compared to 11 or 8 h under 46 to $68^{\circ} \mathrm{F}$. Kvamme (1990) also found similar results of long days by extending a $10 \mathrm{~h}$ day to $18 \mathrm{~h}$ or interrupting the $14 \mathrm{~h}$ dark period with a $4 \mathrm{~h}$ night break at $2 \mu \mathrm{mol} \cdot \mathrm{m}^{-2} \cdot \mathrm{s}^{-1}$. Karlsson (1996, 1997) adjusted the irradiance based on day length to provide a similar daily light integral among treatments. Kvamme (1990) and Welander and Selander (1981) used low irradiance $\left(2 \mu \mathrm{mol} \cdot \mathrm{m}^{-2} \cdot \mathrm{s}^{-1}\right)$ to $\mathrm{ex}-$ tend the short day ( 9 or $10 \mathrm{~h}$ ) to 16 or 18 h. The reported (Karlsson, 1996, 1997; Kvamme, 1990; Welander and Selander, 1981) differences in photoperiodic response, therefore, cannot be attributed to daily light integral. Welander and Selander (1981) studied the Kuiper's strain of 'Aalsmeer Giant' while Karlsson (1996, 1997) and Kvamme (1990) determined the effect of daylength on flowering of the $F_{1}$ hybrid 'Dania'. Cultivars that initiate flowers without a drop in temperature appear to also have altered response to daylength. Long days are more beneficial for flowering of cultivars that do not require low temperature exposure. When natural photoperiods are less than $12 \mathrm{~h}$, extending the day to $16 \mathrm{~h}$ or using $4 \mathrm{~h}$ night interruptions at a minimum of $2 \mu \mathrm{mol} \cdot \mathrm{m}^{-2} \cdot \mathrm{s}^{-1}$ is now recommended in production of english primrose (Table 2) (Linwick, 1996).

Plant morphology. Welander and Selander (1981) suggested that unsightly long and large leaves are correlated to long days or night break treatments and therefore avoided in primula production. However temperature conditions have now been determined more critical than photoperiod for plant morphology (Karlsson, 1997). Armitage and Billingsley (1983) reported more and smaller leaves in polyanthus at $68^{\circ} \mathrm{F}$ compared to $50^{\circ} \mathrm{F}$ although plant leaf areas remained similar at the two temperatures. High fertilizer levels and ammoniacal nitrogen are also factors likely to result in large plants and leaves (Wandås, 1991).

Plant size and maturity. Primula flower initiation probably does not relate to plant leaf area, leaf number or plant maturity. In the english primrose 'Dania', flower initiation wasidentified in plants with 6 to 26 leaves (Karlsson, 1997). At $46^{\circ} \mathrm{F}, 10 \mathrm{~mol} \cdot \mathrm{d}^{-1} \cdot \mathrm{m}^{-2}$ and $11 \mathrm{~h}$ daylength, plants with 6 leaves initiated flowers in $72 \mathrm{~d}$ from seeding. At $68^{\circ} \mathrm{F}$, $2 \mathrm{~mol} \cdot \mathrm{d}^{-1} \cdot \mathrm{m}^{-2}$ and $8 \mathrm{~h}$ daylength, plants initiated flowers in $138 \mathrm{~d}$, but had 26 leaves. Similarly, Welander and Selander (1981) could not correlate plant size with flower initiation in the english primrose 'Aalsmeer Giant' but noted that the leaf number was larger at $48^{\circ} \mathrm{F}$ than at 54 or $59^{\circ} \mathrm{F}$ at the time of bud formation.

Although flowering in primula probably is not dependent on a certain plant size or maturity, at least six leaves formed prior to flower initiation in both 'Dania' (Karlsson, 1997) and 'Aalsmeer Giant' (Welander and Selander, 1981). The higher leaf number at $48^{\circ} \mathrm{F}$ compared to 54 or $59^{\circ} \mathrm{F}$ in 'Aalsmeer Giant' (Welander and Selander, 1981) was inconsistent with several studies which have shown that leaf unfolding in various plant species increases with the production temperature (Erwin and Heins, 1993; Karlsson and Werner, 2001; Karlsson et al., 1988, 1991). If leaf formation is less temperature dependent in 'Aalsmeer Giant', the higher leaf number could be due to the additional time required for flower initiation. In english primrose and polyanthus, flowers form and arise from one area of the apical meristem on individual pedicels (Griffiths, 1994; Salamati, 1988). A close correlation between leaf and flower formation, as expected for plants, which develop flowers in leaf axils, may not occur in primula.

FAIRY PRIMROSE-TEMPERATURE. A drop in temperature for 6 weeks is recommended for flower bud initiation of the fairy primrose (Table 2) (Hartnett, 1993; Karlsson, 1997). The temperature is reduced to between 45 and $50^{\circ} \mathrm{F}\left(7\right.$ to $\left.10^{\circ} \mathrm{C}\right)$ when the plants have reached the desired marketable size. Following the 6 weeks of reduced temperatures, 57 to $65^{\circ} \mathrm{F}$ ( 14 to 18 ${ }^{\circ} \mathrm{C}$ ) is recommended (Hartnett, 1993). The fairy primrose will initiate flowers without a reduction in temperature although the final plant and flower quality may not be as high (Karlsson, 1997; Karlsson and Werner, 1999a).

Photoperiod. Under short days, fairy primrose developed more flowers faster at $59^{\circ} \mathrm{F}$ compared to 68 or $77^{\circ} \mathrm{F}$ (Zimmer, 1985). In studies by Karlsson and Werner (1999a), however, the appearance of flower buds in the fairy primrose 'Prima' was independent of photoperiod when grown at 61 or 68 ${ }^{\circ} \mathrm{F}\left(16\right.$ or $\left.20{ }^{\circ} \mathrm{C}\right)$. Flower buds appeared $20 \mathrm{~d}$ earlier at 61 than $68^{\circ} \mathrm{F}$. The development of buds into flowers was affected by daylength and more rapid with long $(16 \mathrm{~h})$ rather than short $(8 \mathrm{~h})$ days at either 61 or $68^{\circ} \mathrm{F}$ (Karlsson and Werner, 1999a).

Thomas and Vince-Prue (1997) classify fairy primrose as a short day plant. Since the time fairy primrose seed was originally collected in Burma and the Yunnan region of China in 
1908 (Richards, 1993), many breeding selections have been made. 'Prima' is a uniform and early flowering cultivar that may have been developed and selected from breeding lines with good performance under intermediate or long photoperiods.

German primrose-temperaTURE. German primrose is commonly grown commercially at 65 to $68^{\circ} \mathrm{F}$ (Table 2). A reduction in temperature to induce flowering is not recommended (Armitage, 1986; Hartnett, 1993; Karlsson, 1997). Although, the temperature can be dropped to $65^{\circ} \mathrm{F}$ or lower during the final stages of plant development to improve plant quality, flower color and size (Hartnett, 1993).

Photoperiod. Guidelines for producing german primrose usually do not include specific recommendations for photoperiod (Hartnett, 1993; Karlsson, 1997). A high light integral (minimum $10 \mathrm{~mol} \cdot \mathrm{d}^{-1} \cdot \mathrm{m}^{-2}$ ) may shorten the production time, although during the summer, shading is required to control temperature and avoid burning of the foliage. In studies by Karlsson and Werner (1999b), the response to photoperiod was temperature dependent. The german primrose 'Libre' had 0.08 -inch $(2-\mathrm{mm})$ large flower buds $90 \mathrm{~d}$ from seeding when grown at $61^{\circ} \mathrm{F}$ and 8 or $16 \mathrm{~h}$ daylength or under $16 \mathrm{~h}$ at $68^{\circ} \mathrm{F}$. Short days $(8 \mathrm{~h})$ at $68^{\circ} \mathrm{F}$ delayed bud appearance by 2 weeks and flowers failed to develop within $145 \mathrm{~d}$ from seeding. In contrast, long days at $68^{\circ} \mathrm{F}$ resulted in flowering after $111 \mathrm{~d}$. At $61^{\circ} \mathrm{F}$, the primin-free 'Libre' flowered faster under long $(122 \mathrm{~d})$ than short days (133 d) (Karlsson and Werner, 1999b).

The morphology and growth habit of german primrose is highly variable in the natural habitat of the Chinese regions of Yunnan and Sichuan (Richards, 1993). Cultivars and hybrids of german primrose are often produced and marketed under naturally increasing daylengths of spring and early summer. Breeding lines with traits of fast flowering and uniform growth under long day conditions may have been favored in the recent development of the primin-free cultivars.

\section{Nutrition}

Fertilizing should start as soon as the cotyledons begin to develop, about 2 weeks from seeding. The initial fertilizer rate should be low at levels of 60 $\mathrm{ppm}$ of nitrogen and potassium
(Hartnett, 1993; Linwick, 1996). The rate can increase up to 200 ppm nitrogen immediately prior to transplanting. During the production phase, fertilizer rates of 90 to $100 \mathrm{ppm}$ nitrogen and potassium from a complete fertilizer with micronutrients are suitable. Excessive nitrogen and fertilizer easily result in plants with too much leaf growth. Primula is sensitive to high soluble salt levels that may result in necrotic leaf margin burns (Linwick, 1996; Salamati, 1988). Linwick (1996) recommends EC values of $1.25 \mathrm{dS} \cdot \mathrm{m}^{-1}$ (EC determination method not specified). Under growing conditions with low temperature and irradiance, avoid using ammoniacal nitrogen (Dole and Wilkins, 1999; Hartnett, 1993). Plants with unproportionally long leaves may be due to high ammonium nitrogen levels (Linwick, 1992; Wandås, 1991). Micronutrient deficiencies or toxicities are common in primula production and a medium $\mathrm{pH}$ between $\mathbf{5 . 5}$ and 6.2 is essential for micronutrient availability (Hartnett, 1993; Linwick, 1996). Regular monitoring of $\mathrm{pH}$, soluble salts and the nutrient balance in the medium through soil tests is highly recommended.

Holcomb (1983) and Mortensen and Holcomb (1984) described deficiency symptoms of nitrogen, phosphorus, potassium, calcium, magnesium and iron in polyanthus. Nitrogen deficiency appears as chlorosis in newly developing leaves and as a chlorosis and necrosis of older plant tissues. Premature flowering may also occur under nitrogen deficiency. The initial symptoms of a phosphorous deficiency are bronzing of older leaves, inward curling of younger leaves and leaf tip necrosis. Similar to nitrogen deficiency, plants may prematurely flower. Signs of low potassium are chlorotic lower leaves slowly turning necrotic and curling of leaf margins. Some plants may also die following unexpected and sudden wilting with potassium deficiency. Polyanthus grown with low or no calcium had poor root growth and pale green foliage. Magnesium deficiency appeared as interveinal chlorosis with tip and marginal necrosis of older leaves (Mortensen and Holcomb, 1984).

Primula is highly sensitive to reduced iron availability and deficiency symptoms are common (Hartnett, 1993; Holcomb, 1983; Karlsson, 1997; Linwick, 1996; Mortensen and Holcomb, 1984; Wandås, 1991). Styer and Koranski (1997) list primula as an indicator crop for insufficient iron. Early symptoms of iron deficiency are chlorotic new growth followed by completely bleached white tissue due to a lack of chlorophyll (Holcomb, 1983; Mortensen and Holcomb, 1984). Iron uptake and availability are greatly restricted above $\mathrm{pH}$ 6. A boron deficiency initially appears as a light green color later turning into chlorosis of recently matured leaves. The leaves may get cupped or crinkled with leaf edges turning downward. The veins become excessively prominent especially on the lower side of the leaf. If a boron deficiency is not corrected, the apical growing point dies and the stem becomes hollow.

The german primrose requires higher fertilizer levels than the other primula species. Nitrogen rates of 250 ppm with equal or greater potassium levels are recommended for german primrose (Hartnett, 1993; Karlsson, 1997). On the other hand, german primrose and the fairy primrose are highly sensitive to elevated soluble salts, which manifests as leaf edge necrosis. Leaching at regular intervals is recommended to avoid salt build up.

\section{Carbon dioxide}

Primula is a cool temperature crop and greenhouse venting is often limited during long periods of the production. Under conditions with restricted venting, carbon dioxide enrichment at 900 to $1000 \mathrm{ppm}\left(\mu \mathrm{L} \cdot \mathrm{L}^{-1}\right)$ has been reported beneficial for primula production (Karlsson, 1997).

\section{Irrigation}

During germination and early seedling development, the medium should never be allowed to dry out (Aimone, 1987; Cathey, 1969; Karlsson, 1997; Wikesjö, 1975). The seedlings are, however, sensitive to over watering and waterlogged conditions. When seedlings of english primrose and the polyanthus have established following transplant, they can be allowed to slightly dry out before watered thoroughly again. The fairy primrose and german primrose are more sensitive to moisture stress and the media should be kept continuously moist (Hartnett, 1993; Karlsson, 1997, Mureaoka, 2000). Plants allowed to dry or grown at uneven moisture readily develop brown, dried leaf edges. High salt levels in the medium 
result in similar symptoms as water stress in fairy primrose and german primrose (Hartnett, 1993).

\section{Height control}

Final plant height is normally not a problem in primula production. Slightly negative or zero DIF may be used if plant height (peduncle length) is too great (Hartnett, 1993). B-Nine (daminozide) spray applications control height in english primrose, polyanthus, fairy primrose and chinese primrose but are ineffective in german primrose (Karlsson, 1997). Although B-Nine can be used to control plant height, proper spacing, temperature and irrigation are better methods for controlling stem elongation and height in primula than plant growth regulators.

\section{Diseases and insects}

Primula is relatively pest free. Aphids (Aphis sp., Myzus persicae), thrips (Frankliniella occidentalis), whiteflies (Trialeurodesvaporariorum, Bemisia argentifolia) and caterpillars (Helicoverpa zea, Ostrinia nubilalis) are the most commonly encountered pests (Aimone, 1987: Dole and Wilkins, 1999; Hartnett, 1993; Karlsson, 1997). The primin-free 'Libre' is reported to be more susceptible to thrips than primin containing cultivars of german primrose (Mureaoka, 2000). During germination and early seedling development, fungus gnats (Bradysiai sp.) and shoreflies (Scatella stagnalis) may become a problem. Control of algae growth and the use of insecticides may be required to restrict the fungus gnat population during early sensitive stages of plant growth.

Low temperatures and high humidity are ideal conditions for the development and spread of gray mold (Botrytis cinerea) (Chase et al., 1995). Cultural control measures include proper air circulation, sanitation and irrigation practices. Deep planting, which covers the growing apex, predisposes the plant to various soilborne fungi (Phytophthora sp., Pythium sp., Rbizoctonia sp.) that cause crown rot. Overwatering, especially of fairy primrose and german primrose, may result in pythium root rot. Symptoms of pythium root rot include wilted foliage with brown and soft roots (Daughtrey and Chase, 1992). Brown, necrotic leaf spots caused by Ramularia sp. have been observed in english primrose and may later serve as an entry way for gray mold (Aimone, 1987; Hartnett, 1993; Karlsson, 1997).

Tomato spotted wilt virus (TSWV) and impatiens necrotic spot virus (INSV) have been identified in primula (Barnes, 1996; Daughtrey and Chase, 1992; Karlsson, 1997). The symptoms include browning along the veins of the leaves and yellow mottling. No chemical controls exist for viral diseases. The best control of TSWV and INSV is to rouge infested plants and eliminate thrips, the insect vector that spread the virus.

\section{Physiological disorders}

Cultural problems include unattractive plants with long and large leaves. This problem can usually be traced back to high nitrogen and fertilizer levels (Karlsson, 1997; Wandås, 1991). English primrose plants sometimes fail to develop flowers. Exposure to cool temperatures before the plant has developed a good root system or temperatures higher than $68^{\circ} \mathrm{F}$ during the initial stages of floral induction are possible causes for blindness (Hartnett, 1993). Stress at any time during plant development has been suggested to cause elongated flower stems in english primrose similar to the inflorescence of polyanthus.

\section{Postharvest}

Primula is marketed when the first five to seven flowers have opened (Dole and Wilkins, 1999; Nowak and Rudnicki, 1990; Wandås, 1991). Proper temperatures for shipping and holding are 36 to $43^{\circ} \mathrm{F}\left(2\right.$ to $\left.6^{\circ} \mathrm{C}\right)$ and maintaining the plants well watered is vital for longevity. Primula is highly sensitive to ethylene (Dole and Wilkins, 1999). A silver thiosulfate spray application at 65 to $165 \mathrm{ppm}$ (0.2 to 0.5 $\mathrm{mm}$ ) has successfully improved the keeping quality of english primrose (Nowak and Rudnicki, 1990).

The home environment is often at low relative humidity and higher temperatures than the preferred 60 to $65^{\circ} \mathrm{F}$. Although the keeping quality is expected to be limited under these conditions, a high quality primula should flower and remain attractive for 10 to $12 \mathrm{~d}$ (Wandås, 1991). With proper care, the german primrose is expected to continue flowering for 2 to 4 weeks in an appropriate postharvest environment (Hartnett, 1993).

\section{Conclusion}

Primula has been produced for years as a cool season crop. Recently developed production guidelines call for higher temperatures than traditionally used. With proper attention to nutrition, irrigation and other environmental conditions, current cultivars also grow well at reduced temperatures. These findings expand the range of efficient growing conditions for production. For instance, the development of english primrose at $46^{\circ} \mathrm{F}$ approached the rate of 54 or $61^{\circ} \mathrm{F}$ when combined with long photoperiods $(>12 \mathrm{~h})$ at 10 to $12 \mathrm{~mol} \cdot \mathrm{d}^{-1} \cdot \mathrm{m}^{-2}$ (Karlsson, 1996, 1997). Although flowering was delayed at temperatures above the optimum $55^{\circ} \mathrm{F}$, plant quality was still good at $68^{\circ} \mathrm{F}$ (Armitage and Billingsley, 1983; Karlsson, 1997).

Growing conditions with short days appear unnecessary for the cultivars produced today. Long or extended days (14 to $18 \mathrm{~h}$ ) were essential, especially under low irradiance $\left(2 \mathrm{~mol} \cdot \mathrm{d}^{-1} \cdot \mathrm{m}^{-2}\right)$, for fast flower formation in english primrose (Karlsson, 1997; Kvamme, 1990). Similarly, flowering was faster at long $(16 \mathrm{~h})$ than short days $(8 \mathrm{~h})$ for both fairy primrose and german primrose (Karlsson and Werner, 1999a, 1999b).

The many species, cultivars, flower types and colors make primula suitable for a variety of applications and markets. Bedding and landscaping use continues to increase and the potential as a container plant can be realized with innovative marketing. The popularity appears to be everlasting, creating continuous marketing possibilities and opportunities for primula.

\section{Literature cited}

Aimone, T. 1987. Time prime for primroses. Greenhouse Grower 5(5):80, 82, 83-84.

Armitage, A. 1986. Primula obconica: Beauty and the beast. Greenhouse Grower $4(7): 76,79-80$.

Armitage, A.M. and J.W. Billingsley. 1983. Influence of warm night temperatures on growth and flowering of Primula $\times$ polyanthus. HortScience 18:882-883.

Barnes, L.W. 1996. Identifying impatiens necrotic spot virus. GrowerNotes l(1): 13.

Blom, T.J., B.D. Piott, and R. Marchuk. 1987. Primula trials prove cultivar and 
seeding date make a difference. Bedding Plants, Inc. News 18(6):6.

Brickell, C. and J.D. Zuk. 1996. A-Z encyclopedia of garden plants. Amer. Hort. Soc., DK Publ., New York.

Cathey, H.M. 1969. II. Guidelines for the germination of annual pot plants and ornamental herb seed. Flor. Rev. 144(3743):18-20, 52, 53.

Chase, A.R., M. Daughtrey, and G.W. Simone. 1995. Diseases of annuals and perennials, identification and control. Ball Publ. Batavia, Ill.

Chavagnat, A. and B. Jeudy. 1981. Study of the germination in the laboratory of Primula obconica. Seed Sci. Technol. 9:577-586.

Coombes, A.J. 1985. Dictionary of plant names. Timber Press, Portland, Ore.

Daughtrey, M. and A.R. Chase. 1992. Ball field guide to diseases of greenhouse ornamentals. Ball Publ., Geneva, Ill.

Dole, J.M. and H.F. Wilkins. 1999. Floriculture: Principles and species. PrenticeHall, Inc., Upper Saddle River, N.J.

Erickson, D. 1986. Producing primroses. GrowerTalks 50(3):76, 78, 80.

Erwin, J.E. and R.D. Heins. 1993. Light and temperature, p. 55-63. In: J.W. White (ed.). Geraniums IV: The grower's manual. Ball Publ., Batavia, Ill

Goldsberry, K.L. 1980. Primula: A flowering mini pot plant. Colo. Greenhouse Growers Assn. Bul. 359:1-2.

Griffiths, M. 1994. Index of garden plants. Timber Press, Portland, Ore.

Hammer, P.A. 1992. Other flowering pot plants, I. Primula, p. 492-493. In: R.A. Larson (ed.). Introduction to floriculture. 2nd ed. Academic Press, New York.

Hansen, J.V. 2001. Primula ställdes ut i 65 varianter. Viola Trädgårdsvärlden 106(5):24.

Hartnett, G. 1993. Focus on primula production. Professional Plant Growers Assn. News 24(7):4-7, 10-11, 14.

Holcomb, E.J. 1983. The primrose path to nutrition. Greenhouse Grower l(10):224-225.

James, L. and C. Beytes. 2001. International events. Four days at the HortiFair. GrowerTalks 64(9):76-78,80.
Karlsson, M.G. 1996. Temperature, light and daylength for flowering primula. Prof. Plant Growers Assn. News 26(5):10-11.

Karlsson, M.G. 1997. Primula, p. 107111. In: M.L Gastron, S.A. Carver, C.A. Irwin and R.A. Larson (eds.). Tips on growing specialty potted crops. Ohio Florists' Assn., Columbus.

Karlsson, M.G., R.D. Heins, J.O. Gerber, and J.O. Hackmann. 1991. Temperature driven leaf unfolding rate in Hibiscus rosasinensis. Scientia Hort. 45:323-331.

Karlsson, M.G. R.D. Heins, and J.E. Erwin. 1988. Quantifying temperature-controlled leaf unfolding rates in 'Nellie White' Easter lily. J. Amer. Soc. Hort. Sci. 113:70-74.

Karlsson, M.G. and J.W. Werner. 1999a. Rate of flower formation in Primula malacoides varied with photoperiod and temperature conditions. HortScience 34(3):476 (abstr.).

Karlsson, M.G. and J.W. Werner. 1999b. Daylength and temperature affect rate of flowering in Primula obconica. HortScience 34(3):476 (abstr.).

Karlsson, M. and J. Werner. 2001. Temperature affects leaf unfolding rate and flowering of cyclamen. HortScience 36:292-294.

Kromer, D. 1991. Premium primula. Greenhouse Grower 9(6):104.

Kvamme, T. 1990. Virkning av temperatur og lys på vekst og blomstring hos symre primula (Primula vulgaris Huds.). Hovedoppgave ved Norges Landbrukshøgskole, Ås, Norway.

Liberty Hyde Bailey Hortorium. 1976. Hortus third: A concise dictionary of plants cultivated in the United States and Canada. 3rd ed. Macmillan, New York.

Linwick, T. 1992. Culture notes on primula. GrowerTalks 56(3):19.

Linwick, T. 1996. Primula culture made easy. GrowerTalks 60(2):47, 52 .

Löfenberg, E. 1988. Kylperiodens och drivningstemperaturens effect på utveckling och kvalitet hos Primula vulgaris. Trädgård 341. Swedish Univ. Agr. Sci., Alnarp.

McNertney, D., M. Khademi, and D. Koranski. 1991. Raise your primula germination rates. GrowerTalks 55:(8):43, 45.

Miller, E.A. and E.J. Holcomb. 1982. Effect of $\mathrm{GA}_{3}$ on germination of Primula vulgaris Huds. and Primula $\times$ polyantha Hort. HortScience 17:814-815.

Mortensen, W. and E.J. Holcomb. 1984. Nutrient deficiency symptoms on primula. Pa. Flower Growers 352:1, 6, 7.

Mureaoka, K. 2000. Culture tips for primula. Greenhouse Product News 10(9):20.

Nau, J., 1999. Ball culture guide. The encyclopedia of seed germination, 3rd ed. Ball Publ. Batavia, Ill.

Nowak, J. and R.M. Rudnicki. 1990. Postharvest handling and storage of cut flowers, florist greens and potted plants. Timber Press, Portland, Ore.

Perry, L.P. 1981. Primulas make a comeback as a 5 -month cool crop. Flo. Rev. 168(4344):22, 55 .

Professional Plant Growers Assn. 1994. Growing basics for primula. Prof. Plant Growers Assn. News 25(10):5.

Richards, J. 1993. Primula. Timber Press, Portland, Ore.

Salamati, S.Z. 1988. Vekst, blomsterdifferensiering og blomstring hos kusymre (Primula vulgaris Huds.). Hovedoppgave ved Norges Landbrukshøgskole, Ås, Norway.

Selander, C.S. and N.T. Welander. 1984. Effects of temperature on flowering in Primula vulgaris. Scientia Hort. 23:195200.

Styer, R.C. and D.S. Koranski. 1997. Plug and transplant production: A grower's guide. Ball Publ. Batavia, Ill.

Thomas, B. and D. Vince-Prue. 1997. Photoperiodism in plants. 2nd ed. Academic Press, San Diego, Calif.

Wandås, F. 1991. Primula vulgaris (acaulis), en odlingsbeskrivning. Trädgård 361. Swedish Univ. Agr. Sci., Alnarp.

Ward, P. 1997. Primroses and polyanthus: A guide to the species and hybrids. Batsford, London.

Welander, T. and C. Selander. 1981. Flower formation in Primula vulgaris. Swedish J. Agr. Res. 11:41-47.

Wikesjö, K. 1975. Primula $\times$ acaulis and Primula $\times$ polyantha som krukväxter. Trädgård 89. Konsulentavdelningens Stencilserie, Alnarp, Sweden.

Zimmer, K. 1985. Primula, p. 137-138. In: A.H. Halevy (ed.). Handbook of flowering. vol. IV. CRC Press, Boca Raton, Fla. 